Kohl: a Journal for Body and Gender Research

Vol. 3, No. 1 (Summer 2017)

\title{
Bodies of Hope and Disruption
}

\author{
Jillian Grisel
}

\begin{abstract}
:
One way neoliberalism and patriarchy maintain power is under racial hierarchies that legitimize the removal of non-white bodies to places of disposability. I aim to illustrate this violence and how it plays out through migrant domestic workers in a Lebanese context, tracing their pathway to incarceration. I also attempt to dispel the myth that suggests migrant domestic workers are victims in their location of disposability through my experience facilitating a mental health intervention in a Lebanese prison. I demonstrate this by reflecting on how Western medicine reinforces the oppression of migrant domestic workers relative to my own subjectivity and how they resist through acts of feeling and care-work.
\end{abstract}

\section{Dedication:}

This piece is dedicated to Dr. Sawsan Abdulrahim whose commitment to social justice continues to push me to do the challenging work of self-reflection required of a Feminist researcher. Her ethical integrity gave me the courage to write this piece with bald honesty and in the process, has contributed to much of my own healing, for which I will always be grateful. 
Our skin is the largest organ of our bodies - eighteen square feet of fibers that hold our minds, hearts, and guts together. The skin is the first sensory medium that gives meaning to the outside world, and often the last to go out. As a complex that houses feeling, both the expressed and unexpressed, it is the very fabric that holds our subjective memory, connecting us to information that transcends immediate experience. Traditional healers identified the body as a freeing tool for knowing, making sense of the world and finding our place in it. These were my thoughts, my heart's focus, as I stood in a solitary confinement room in a Lebanese women's prison, a space that was less than half the square-footage of my own skin that was holding me together. Even though this lock-down facility was within twenty minutes walking distance to the center of Beirut, almost everyone I talked to on the outside did not know it existed. Over half of the incarcerated were non-Lebanese nationals, refugees, or former migrant domestic workers (MDW's), criminalized and funneled here to be out of sight. ${ }^{1}$ I was brought back into the moment as the guard directed me to finish the prison tour. She explained the layout and I listened to what made sense; sometimes they mixed, but overall the women were separated in cells per varying shades of melanin. Skin was the ultimate organizer.

As a graduate student at the American University of Beirut, I was granted entry into the prison to facilitate a mental health intervention under the guidance of an advisor and the Internal Security Forces (ISF). The project was deeply personal having had a parent incarcerated and because of my own struggles with mental health issues related to gender violence and religious oppression. Since I was a former massage therapist, those incarcerated and the prison doctor thought it would be best to use therapeutic touch as the main component of my intervention. I was there to teach the prisoners massage therapy using participatory methods, that despite it being controversial, also included the guards. Though critical scholarship reveals the material role skin plays in organizing, not just our guts, but the world around us, much is not understood still about our largest organ, the role it plays in perception and the healing process. In designing and implementing the intervention with the women prisoners, we meant to co-create a wellness tool the prisoners could use in their daily lives, illustrate how touch therapy impacted the women and prison space, and in so doing, shed light on the ways in which current Western institutions, including Western medicine, reinforces female oppression.

In this article, I follow in the tradition of Black, Indigenous and Transnational Feminisms that look at nonrational and non-linear ways of knowing as linked to the psychic, emotional, and spiritual (Allen, 1996; Alexander, 2005; Lorde, 2012). These components deepen experience and without them, we can never really know ourselves, causing a conflict between what our body knows and what our mind has been programmed to forget (Lorde, 2012; Alexander, 2005). I also assume here that the present moment is a holding of the past

1 "Funneling people to prison" is a common term uses to describe structural processes in place that influence life pathways to prison. I have seen it used in a Western context describing pathways to prison as forced migration due to the Prison Industrial Complex. Since certain populations are more vulnerable to being incarcerated on a global level, specifically women of color, it is meant to highlight that those being incarcerated are not doing so because of individual failures but because of structural issues. 
that makes up multiple realities in the material world. Consequently, bodies are spaces that hold generational memory, a framework developed by Lebanese Feminist, Deema Kaedbey, termed Shadow Feminism (Kaedbey, 2015). These frameworks proved helpful in untangling my own subjectivity having a Mormon background, a unique form of Christianity, with patriarchy as a guiding cultural and spiritual tenant. I grew up with knowledge of my polygamous ancestry and the various manias my grandmothers developed. From an early age, I developed a distrust for Western medicine after witnessing virtually every woman in my family be medicated or institutionalized because of addiction or mental health disorders. While these determinants made me relatable to the prisoners in Lebanon, specific contexts and experiences do not translate through citizenship, race, and geographic histories. I recognize such biases by defining my own positionality in this article as relative to the women I worked with and subsequently outline how the larger forces of patriarchy, capitalism, and white supremacy shape MDW's pathways to prison. And finally, through my experience facilitating a touch therapy intervention, I reflect on the failure of the linear model of diagnosis, a model influenced by French and American thought, in capturing the complexity of health and discussing how the incarcerated MDW's resisted through acts of feeling and care-work.

\section{The Path to Prison for Migrant Domestic Workers}

Social waste has always been a defining factor of capitalism. The West has built and exported the prison industrial complex where, globally, women from Africa, Asia, the Middle East, Latin America, or with Indigenous, Black, and Latina backgrounds make the fastest growing prisoner population in the world (Sudbury, 2005; Walia \& Smith, 2013). These pathways are related to globalization, the feminization of carework, and Western imperialism (Walia \& Smith, 2013; Sudbury, 2014). The efficiency model that dominates global humanitarian efforts, with its continuous generation of quantitative evidence, forms a discourse of weakness and victimization that characterizes MDW's: poor women of color who have histories of trauma (Sudbury, 2005; Pande, 2012). In Lebanon, there has been an influx of MDW's in the past decades, and while the numbers are harder to trace in terms of who is entering prisons in Lebanon, themes around their life center around victimhood and slavery and constitute the dominant discourses when attempting to determine solutions (Pande, 2012). Assumed as facts, these viewpoints further alienate these women from civic life, not just by hiding them, but by presenting them as troubled and in need of treatment. My piece aims to reject that notion by dispelling the myth of victimhood as I focus on MDW's from Africa, South East Asia, and the Philippines who are a transnational labor force that make up the bulk of care-work in Lebanon (Pande, 2012).

My theoretical frameworks recognize that Western institutions, such as the medical field and academia, produce much of the evidence that legitimizes the oppression of women. As authorities of knowledge, these industries generate information that drives policies and sets the standards by which some bodies are deemed worthy of disposal. Historically, when women deviated from patriarchal norms, they were put in psychiatric institutions and locked away as hysterical and mentally ill (Davis, 2011; Brumberg, 2010). Now, prisons have 
replaced psychiatric institutions, with state measures of control tightening their grip on migrating non-white women that embody transnational flows of capital (Chang, 2000; Sudbury, 2014). ${ }^{2}$

Through oral testimonies, MDW's are giving perspective to how environmental structures in Lebanon, such as low pay, harassment, racism, a lack of employer accountability to abuse, and detainment shape their lives (Gemma, 2016; Mala, 2016; Rose, 2016). Consequently, MDWs are vulnerable to mental health strains related to environmental factors with suicide as a major health concern among them (Pande, 2012). Although international organizations acknowledge that mental health disorders are related to wider forces, treatment rarely happens beyond the individual because of the political costs. The World Health Organization (2016) recognizes that social determinants are instrumental in guiding health outcomes and are defined as the conditions in which people are born, grow, work, live, and age, and the wider set of forces and systems shaping the conditions of daily life. These forces and systems include economic policies and systems, development agendas, social norms, social policies, and political systems (WHO, 2016). Thus, the prevalence of mental illness among the imprisoned MDW's I worked with was far more complex than a biological manifestation and, like their incarceration, can be traced to the policies and social structures of neoliberal and patriarchal ideology.

Since the 1980s, neoliberalism has been the main ideology behind the world's economic policies, calling for free markets and little government regulation (Harvey, 2005). Global financial markets were created as countries restructured their governments by privatizing public services, such as education and healthcare, to meet requirements issued by Western development agencies who granted loans only under such stipulations (Farmer \& Sen, 2003). These financial markets are the global capital mechanisms in place that now indebt countries, create vast income inequalities, and widen health disparities (Farmer \& Sen, 2003). The austerity measures neoliberalism requires as a result of structural adjustments leave specific populations vulnerable to dispossession while also limiting their economic choices. Complicating this for women, the global economy is also structured in a way that is dependent on the patriarchal notion of gendered cheap labor, with countries' economies being "feminized" to enable women from richer nations to manage their home lives according to the social expectations demanded of them while also not disrupting the patriarchal order of the system at large, primarily by employing MDW's (Parreñas, 2008). Neoliberalism sets the stage for producing social waste in its contradiction of claiming regulation under a society of equal opportunity while eliminating the very social services that enable those opportunities. Patriarchy further contributes to the production of social waste by setting limitations to what kind of work women are permitted to do while also devaluing care-work into commodified cheap or free labor (Parreñas, 2008).

In the case of Lebanon, the influx of MDW's is an extension of neoliberal policies and their path to prison is part of the same project of keeping capitalism in place through racial hierarchies (Walia \& Smith, 2013;

2 "Non-white female bodies" will be used synonymously with the term "women of color" and defined as those from the Middle East, Asia, Africa, Latin America, and Indigenous communities. According to Julia Sudbury, leading activist scholar in the prison abolitionist movement, these are the populations that represent the fastest growing prisoner population world-wide. 
Pande, 2012; Smith, 2015). Like other countries, Lebanon felt the pressure of competing interests with the transforming global economy and made structural adjustments during the oil boom in the 1970 s to promote growth. Simultaneously, there was a shift in hiring women from Africa because their labor was less expensive and assumed to be more subservient (Pande, 2012). Their continuous influx, in turn, has lowered the social status of domestic workers, and given domestic work a negative racial connotation, revealing how brown bodies are seen as justifiably disposable and as an anchor of capitalism (Pande, 2012; Smith, 2015). In the prison I worked in, the MDW's accused of violent crimes were women who had fought back against their employers after being tortured or withheld pay. The women who were criminalized for sex-work or theft were resisting through survival strategies of being withheld pay as well. However, some never stole money; it was just a way for the employers not to have to pay the worker. Respectively, I was working with a unique population who, through their dissent, resisted gender, racist, and economic violence, and were simultaneously an extension of it in a site meant to keep them invisible.

\section{The Medicalization of Misery}

According to the prison doctor, everyone who entered the prison after being criminalized was evaluated by a psychiatrist and almost always diagnosed with a mental disorder. In the rare cases that they were not diagnosed, the doctor specified that the prisoners would eventually develop a mental disorder because of stress related to the prison environment. The reason the doctor advocated for a touch therapy intervention simply came down to validation of experience and a lack of resources. She was clear in her position that she believed the women were not ill, but merely victims to life circumstance, stating: "Their pain comes from someone not being there." Intuitively, she was witnessing the "medicalizing of misery," a phenomenon I saw with the women in own my family. By pathologizing oppression and resistance, I saw how the medical field dismissed intersecting class, religious, and patriarchal oppressions, and after much study, realized the essential role psychiatry has had in moving capitalism forward through androcentric clinical diagnosis (Metzl, 2003; Ussher 2010). I was able to reframe my grandmothers "manias" into resistance strategies that informed my judgments about the women I worked with in the prison. While my subjectivity was not transposable to their experiences, I assumed they faced similar oppressions related to the interconnectivity between hegemonic ideologies, capitalism, and Western medicine.

I met one of the prisoners, Natalie, for the first time in the English classes I taught at the prison along with the massage courses. The English courses were set up to provide a comparison for the group dynamics that formed within the first few sessions of each class. ${ }^{3}$ The Lebanese women did not want to learn English with the non-Lebanese women; however, they had few issues about learning massage together. Natalie, a Sri Lankan women, was an exception and learned English with both groups. Natalie had just been transferred

\footnotetext{
3 We learned English using comic books made by U.S. prisoners. Although the comics were from a western perspective, the women narratives in the comics resonated because of the role gender and race play in causal pathways to prison. I want to give a special thanks to Dr. Lisa Armstrong for introducing me to these resources and to the Real Costs of Prisons Project: http://www.realcostofprisons.org/comics.html
} 
from another prison, and despite dominant racial hierarchies within Lebanon, held much clout among all the inmates and guards. She came to class late, interrupting our introductions. Cracking a smile, I said, "Looks like we have a trouble maker here." She smiled back. Natalie had spent over a decade in prison. She had come from extreme poverty to Lebanon and hoped to make money for her family like many other women who enter domestic work. Met with the restriction of the Kalafa system, she was matched with an employer who abused her without any accountability. She was locked in tiny rooms, beaten, starved, and physiologically tortured with sleep deprivation. After a year, she confronted her madam who slept with a knife under her pillow. There was an argument, and Natalie stabbed both the madam and husband, killing the madam instantly. She pled guilty, had poor legal representation, and since she was criminalized for murder, her embassy abandoned her.

Natalie would not come to the massage classes and I did not push her. She peeked her head in the classroom and the other prisoners and social worker whispered her story to me. The prisoners were expecting me to be judgmental or perhaps take the usual sympathy/pity response one gives to hearing a tragic narrative. One woman winced and said, "They should let her out, she has changed so much," as if to ease the news. Natalie came back in the room knowing we were talking about her. She looked at me, trying to read if I would withdraw, trying to sense if I feared her. We did not say anything for a moment. I then told Natalie, "You fought back and if you hadn't you would have eventually ended up dead." She said nothing to me and smiled warmly. She not only came to my classes after that moment, she would also warmly touch my arm every time she walked passed me.

Natalie's narrative is a story replete among women throughout all of time who never escaped the insults of learned silence, the slow violence stealing lives from one generation and making it nearly impossible to trust one's self through the denial of experience. Between the incarcerated women, touch became a tacit expression, an energy transfer needed to bring voice to the silence. It was a way for us to witness each other, validate, and build mutual respect despite our differences.

My belief that Western science was failing the MDW's is supported by Lamia Moghnieh, a Lebanese scholar in anthropology and social work, who warns Lebanese psychiatrists, psychologists, and humanitarian groups of their treatment protocols for women, especially those who are dispossessed. She argues that because they are informed by American and French psychological thought, they are over diagnosing with "conversion disorder," a present-day form of hysteria. She calls for a spirit of caution among Lebanese mental healthcare providers in their approach to "uncritically diagnose" (Moghnieh, 2014). While she critically and rightly calls attention to the treatment of women, she also points to how a Feminist movement has been able to change some of this thought. Touch therapy is advantageous because it has an ability to go beyond the scope of what western medicine captures, and although controversial, counters the concept of linear time by accessing subjective spiritual reserves linked to historical trauma when addressing oppression related to health and problem solving. 


\section{Touch Therapy as Trauma Intervention}

In my first class teaching the women prisoners, I introduced myself. I let the women know that I was a massage therapist and that we would be working with touch therapies to achieve better feeling states. I had spent time in Thailand learning Thai massage and theory along with other Indigenous health systems, specifically Hawaiian, that worked with energy rather than Western diagnosis. The Hawaiian health system assumes the body as a reference point of knowing, and through bodywork and engagement of emotions, one is able to tap into spiritual reserves that connects all through ancestral wisdom, past, present, and future, and is the only true source of knowledge production (Jim, K. H. U., \& Arledge, 2007). I see this space as what Transnational and Black Feminists refer to as the sacred and is linked to the feminine energy of creation (Lorde, 2012; Alexander, 2005). This space is more than an abstract concept, and to access it takes emotional and spiritual labor that requires commitment to quality of presence that, in turn, impacts what we are doing. It is in this space that systematic oppression can be disrupted because as we integrate our subjective inheritances in a way that contribute to our own awakening, we in turn link individual struggle to collective resistance through the sacred that connects everything (Van Dernoot Lipsky, 2010). While it may be hard to take this approach seriously for many, my belief in bodywork came by working through my own trauma and is an essential part of what made me relatable to the women I worked with in the prison, as I looked beyond diagnoses and criminalized behavior.

In my own struggle with mental health, I resisted through seeking alternative health methods, trained as a massage therapist, and began my own private practice as soon as I graduated from school. Being young and inexperienced, I was quickly confronted with the realities of sexism, assault, and coerced transactional sex that are rampant in the massage industry. Like most, I was not aware that I was being initiated into the shadow economy of sex-work that resulted in much trauma that I am still uncovering. However, my reflections have brought to light different viewpoints that I am still untangling, and in their complexity, counter the victimization narrative of sex-work. ${ }^{4}$ On one hand, as one who was religiously socialized to view men as the ultimate power, I did not have the skills or consciousness to navigate safe boundaries. On the other, despite sex-work's dangers, I saw that intimate relationships with men as a gateway to marriage was far more oppressive, having experienced how the privatized nature of the nuclear family protects abusers. Sex-work, for me, became an act of resistance, a safer place because it guaranteed more autonomy in my current paradigm at the time. I won't say it was freeing, because it was not; rather, it gave me more freedom to not have to take on the responsibilities expected of a Mormon wife and make the oath of obedience to a husband through the patriarchal order for time and all eternity, as required in the Temple ceremony. I would later go through the temple ceremony in an attempt to integrate back into my community but would eventually break my covenant after reading the lost histories of Mormon women being recovered by Mormon Feminists today. I found in these narratives that women and patriarchal gender structures were central to building the Mormon economy in Utah, and although in moral conflict with each other, polygamy and sex-work were practiced and

\footnotetext{
${ }^{4}$ My narrative further complicates the notion of sex-work as my experience as a sex-worker was limited to oral sex. Since I had not had intercourse yet, my John felt my worth was elevated, and wanted to keep me pure by limiting what sex acts I did.
} 
regulated openly in the Mormon landscape until plural marriage was abolished (Nichols, 2002). In hindsight, I will say it was a familiarity of generational programming: although I was countering the norms of my community, I was still answering to a male authority and reenacting the dynamics of polygamy, the culture around its secrecy, and the brokering of women like human chattel (FMH, 2012; FMH, 2014).

I realize the risk of disclosing my positionality, but as a transnational and intersectional feminist act of solidarity, it is an attempt to destigmatize sex-work, while also recognizing how my American white privilege were key factors to why I was never incarcerated and had access to higher education. Like in my own life, these ideologies deny women's feelings, and oppression begins because it denies a large part of women's experience, creating an inward dissonance that makes room for outward sources to assert themselves as stabilizers of control (Lorde, 2012). In this sense, this sheds light on the advantages of bodywork as it provides a non-invasive medium empowering those experiencing it to reclaim their mind by putting them in touch with feelings felt in the body (Fogel, 2009). Also, bodywork allows for emotional processing in a way that does not require a person to re-live painful memories or risk cultural repercussions by re-telling events (Fogel, 2009). Now with new fields in science recognizing generational trauma termed Epigenetics, using the body as a medium to heal is that much more important. This is especially helpful with those who have religious or cultural shame behind their experiences and where language barriers are issues, all of which were applicable to the women I was working with. Perhaps the most important use for employing touch therapies, though, is that by putting one in touch with themselves and their surroundings through their bodies, they are able to claim it as space, a critical factor to wellbeing for women in an environment, like prison, where at any given time they can be strip searched, handcuffed, or put in solitary confinement.

Solitary confinement was the most common tactic to exert control over the women in the prison. In my community assessment, both the guards and the prisoners were vocal about it as the incarcerated women were in a perpetual state of fear from its constant threat. Solitary confinement is a common practice in punitive justice systems and now internationally recognized as one of the most devastating ways to induce psychological trauma termed Sensory Deprivation Torture (SDT) (AI, 2014). According to a Lebanese prison doctor I interviewed, who was also a former political prisoner subjected to SDT for fourteen years, the impact was worse on the inmate than any anything else. Human rights organizations like Amnesty International and the UN expert on torture have specifically condemned the use of SDT on mentally-ill persons (CCI, 2012, Heiss, 2015). SDT disorients the inmate by causing them to lose parts of their personal identity that induce the same symptoms as the mental disorders the prisoners were labeled with in the first place $(\mathrm{CCl}, 2012)$. SDT is always used to repress, and the first time I saw it enforced in the prison was over a power-struggle with water. The water had been turned off for three days and all the inmates were not able to wash themselves. A prisoner was told she could not take a sponge bathe and became angry when another inmate, one of higher economic status, was granted permission. She was put in solitary confinement and the nurse told me she had a history of anger related to her mental disorders.

Bodywork counters the disorientation of SDT and consequently is highly political. Such healing work is the antidote to oppression, and that means knowing ourselves through the sacred, which requires a rewiring of the senses (Alexander, 2005). Our skin is that medium for such work and should be the center of all healing 
work in a world where bodies are commodified to be in service of capitalism (Alexander, 2005). Massage therapy and sex-work are forms of care-work, and having experienced both, I felt the struggle and negotiated parts of myself on what it means to commodify our most social sense and connection to spiritual reserves that enable us to remember purpose and give life meaning through interconnectivity (Alexander, 2005).

Since power hierarchies are so embedded in Western medicine and the prison system, the prisoners and I attempted to minimize authoritative tendencies that could interfere with self-exploration. Thus, we established a giver and receiver relationship. The idea is simple; the receiver's body knows what to do, the giver only facilitates the process with presence of mind, acting as a witness to what the receiver resolves on their own. The validation of such self-discoveries then promotes self-trust within the receiver, allowing them to reclaim their body and mind. My first demonstration was given to Mable, a Filipino woman, and after her experience, she teared up and said, "I feel free." It was an emotional moment for all that came to the class. For most women, including myself, being introduced to respectful touch after years of abuse or neglect from touch is a powerful remembering.

Therapeutic touch, among other alternative methods to managing mental health, is still on its way to being taken seriously as "safe" and "evidence-based" in psychiatric medicine. However, its ability to facilitate the healing process is the foundation for many non-Western health systems across the world and has been practiced for thousands of years to not only heal chronic and acute pain, but to build trust and instill perceptions of equality that truly lay the foundation for full democratic participation (Field, 2014). Thus, Moghnieh's suggestions are invaluable to providing comprehensive mental health services in Lebanon and precisely describe the backlash I received using touch therapies with prisoners as the main component for my intervention. The person who was the most critical of the intervention was a psychotherapist influenced by American and French schools. They claimed that touching trauma victims, especially between prisoners and guards, would lead to further issues of abuse. They stated that, from their experience, the healing process for people who were victim to any type of physical abuse, required absolutely no touching. This perspective can be traced back to Menninger, one of the leading American psychiatric theorists who labeled all touch to be the "mark of a ruthless criminal," making its association with criminality a cultural norm in American society.

Attitudes among Western academics also reveal racist and colonizing insights embedded in methodologies of study around sensory engagement and knowledge production. For example, in the 19th century, natural historian Lorenz Oken theorized that some races were deemed more civilized based on how they interacted with the world. He proposed that the European "eye" man, who relied on the visual world as a way of knowing was superior to the African "skin-man" who relied on feelings he felt through the body (Classen, 2012). To be respectable, Oken claimed that one must rise above the animal kingdom and in turn reject the body as an avenue of intelligence especially in the representation of scientific work (Classen, 2012). Western societies are now facing what physician P.N.K. Heylings terms a "no touching epidemic" with symptoms including feelings of isolation, doubts about other people's loyalties, feelings of insecurity, emotional inhibitions, and inability to communicate with people standing nearby (Heylings, 1991). All of these feelings describe the backbone of neoliberal power-competing interests, insecurity and, most of all, fragmentation. 
As demonstrated, isolation is an underpinning of oppression and was a major tactic in controlling the prisoners while inducing psychological trauma. On the outside, MDW's have documented through oral testimonies the use of isolation by the ISF as their first experience when migrating to Lebanon (Gemma, Rose, Mala, Meriam, \& Julia, 2016). There are also attempts to isolate the MDW's in the employer's house, and yet despite this, they resist. I found the same to be true within the prison space as well, and like most forms of resistance, it begins with struggle through proximity and validation, and to my surprise with MDW's, honoring and acting out on feelings in the body despite the repercussions.

\section{Touch Therapy in the Prison Environment}

In class when I was teaching, some just wanted to watch instead of participate, including Natalie and a few Lebanese prisoners. I was demonstrating a massage technique and as I bent over, my shirt rolled up showing my back tattoos. One of the Lebanese women saw and started asking me questions about them. I pulled my shirt down but the woman pressed on and moved my shirt up with her hand. I pushed it away and asked her not to talk about it because the guards would get upset from us not staying on task. The guards were moving freely throughout our teaching area and tattoos could be culturally taboo among certain groups in Lebanon. Depending on the background of the guard, I was afraid I would be given a harder time if it were common knowledge that I had body ink. The woman persisted so Natalie stepped in and told her to stop. She was kind but stern and the Lebanese woman sat down and was quiet. In her effort to set a boundary between the Lebanese prisoner and I, I realized Natalie was becoming protective of me. She looked at me with a nod. It was a silent communication, but I knew what she meant; she had established a power differential with the Lebanese women.

The fact that Natalie, along with the other incarcerated MDW's, were imprisoned rather than sent to a detention center points to a level of resistance and spirit that is rarely captured because of their invisibility. Furthermore, despite the racial hierarchies that contribute to their disposability, Natalie, along with the other domestic workers, was able to establish power. Interestingly, although they were reenacting the racial hierarchies from wider society, their care-work was not commodified; instead, it acted as a social currency giving them advantages of spending more time and building relationships that essentially gained them trust. This resulted in more time outside their rooms, getting to walk out of the prison with guards to help bring in food, and leading intakes of new prisoners with the nurses. Mable, a Filipino woman who was incredibly powerful with her relationships with the guards and nurses, even led intakes with new women, being left alone in a room with the door cracked open from time to time. In this respect, as the first prisoner to encounter those entering, she immediately established a powerful position with the new-comers.

Also, the time the women spent massaging the guards were crucial moments of relief that were felt throughout the whole prison. These small moments of caring attention helped to ease tensions that burdened the guards from life worries, making them more patient in general. Originally, the intervention only included the prisoners, but due to resentments from the guards, the prisoners and my advisor suggested to include them. Thus, the 
motivation for the intervention for the prisoners was to ease psychological stress related to immediate environmental issues and to manage power struggles that put the prison community in crises, rather than to merely manage biological pathologies, such as mental disorders. Since the intervention permitted more open acts of caring touching, the former domestic workers strategies of tactile engagement allowed them to build relationships vertically and horizontally, essentially being a powerful force in managing the prison space. ${ }^{5}$

Probably the most crucial example of the incarcerated domestic workers resisting was through the expression of outward emotions and feeling. From the beginning, I had tensions with the guards who routinely patted me down that continued to escalate. For myself, I was not honest with what I could handle with the emotional burdens of the intervention. In my naivety, I openly expressed empathy with the prisoners in a class after a former MDW found out that her embassy had abandoned her. She was a woman from Kenya and her mother and son lived off her remittances. She was accused of stealing hundreds of thousands of dollars from her employer and was told she would receive no help. She ran into the classroom into my arms and pulled at my shirt while she collapsed, crying and shouting "if I had the money, my child wouldn't be starving!" I made a conscious decision to cry with her, prompting the other women in the class to cry as well. A social worker saw us, and from there it steamed rolled into more surveillance over my classes.

Mable chastised me for this, showing her confidence as a leader. She told me I would be "eaten alive" and that crying with prisoners publicly was too dangerous. She said, "If you feel something, go home, don't come. It took me three months to be able to cry here." She was stern and made me rethink my ethical obligations as a facilitator and what it means to act in a way that could potentially put everyone in danger. I realized how risky the intervention was, that to simply feel as a way to process trauma and transform it, was in complete conflict with the prison space itself. In fact, that was its function. Since that time, I have come to realize neoliberal and patriarchal ideologies are not the exclusive domain of governments and economies, but underpin ways of thinking that produce academic scholarship, research, and medicine.

Towards the end of my three-month work, the prison went into crisis for detaining a political prisoner. The woman was an attempted suicide bomber, and rather than be placed in a room with those who were her same race and nationality, the guards had her room with women from Africa. It did not make sense, but the guards claimed it was for her protection because she would be killed if she was in any other room. After a few days, Mable approached me and told me not to come back for a bit because horrible things were happening in the prison. I listened to her and on my return the following week, I noticed one of the women that was rooming with the political prisoner was out of her cell. Her name was Taana and she was from Ethiopia. She told me that she would love to come to my English class that day if I was willing to teach her

\footnotetext{
${ }^{5}$ Although households and prison space are both confining and oppressive for MDW's, they agreed that the prison space was more freeing because they were able to socialize with other women regularly with designated breaks and sleep. I assume this perspective would not be generalizable among all MDW's since those entering were doing so for criminalize acts of resistance against employers that were exceptionally abusive. However, this adds to MDW's challenging of spaces of exclusion by reclaiming it through relationship building by proximity and warrants more investigation in terms of how it impacts MDW's resistance in general.
} 
alone. She said, "they will let me go, if you ask for me." As she walked back to her room, everyone, from the guards to the prisoners, described her as simply crazy.

I pulled Taana from her room and after we settled, she told me that she did not want to learn English, she just wanted to tell me what was going on in the prison. She told me that when the political prisoner arrived, she had been tortured with burn marks all over her body. She was sick, hurt, and moaned all night. Taana said quietly, "She needs medical attention, soap to clean herself, and food. The guards told our room that we were not allowed to give her food or soap. Everybody in my room won't give her food or care, but not me. I can't watch her die and fuck them." She then looked at me and said, "People don't like me because I gave her my food and soap. I won't stop. Kill me. They tell me I am crazy, but if that makes me crazy, then I am crazy." Taana proceeded to explain that as a result of being caught, one of the guards held her down on the bed and beat her while making all the other women in the room watch. Even though she could not turn her head or lift her arm and parts of her face were swollen, Taana was not scared. Before we ended the session, she had a huge grin on her face, hugged me and said "I am crazy. Fuck this place."6

Taana's willingness to take on "crazy" as a resistance identity to explain her compassion stares right into a system's eyes that gets its power by pitting people against each other. I watched the social workers, guards, and nurses all struggle to understand her through a label, and when they did not have a word, it just went to "ma ba'rif, hiyya majnoona," meaning "I don't know, she is crazy." Looking at the wider forces, we see how neoliberalism breaks down relationships through competition, globalized markets, and the illusion of individual responsibility that breeds isolation. As a global phenomenon, it specifically targets women of color, producing social waste, and moves them out of site. Furthermore, through Feminist frameworks, we see how patriarchy uses domination and paternalism to control, splitting self by pitting reason against feeling. And last, the invisibility of both are made possible by Western psychiatry and its nature to focus on the individual and rejection of the sacred, making us forget ourselves and how we are connected to the past and present. Thus, our ability to truly heal becomes virtually impossible without access to such spiritual and emotional supportive reserves. Furthermore, through its assumed position of objective analysis informing judgments, it works in tandem with the justice system that fractures context by capturing only one point in time. It is messy, violent, and exhausting. However, it should not over-shadow Taana's perspective, a vital answer, that despite the repercussions will "Fuck this place" by honoring what she feels.

Outside of prison in Lebanon, strides are slowly but surely being made with MDW's through organizing and petitioning to unionize. This is accumulative resistance that can be traced to MDW's strategic acts that challenge the spatial exclusions they experience by using the spaces as sites of resistance to talk, gain information from one another, and act. This highlights how MDWs are not passive agents in a country that has forbidden them to form a union and self-determine through bargaining rights, despite the fact that two key MDW activists were recently detained and one deported (Khawaja, 2016). In the prison, the same can be seen in those whose work and bodies have been commodified. Taana resisted using acts of care, as well

${ }^{6}$ I reported this abuse to an international agency but after consulting with an advocate determined that addressing the situation would cause more harm in the long run for the prisoners involved. 
as the other women in the prison. The acts of the resistance, including through touch and relationships, may seem individual or trivial, but they are in fact powerful because of what they represent in relation to honoring one's emotional truth and how it connects to the collective struggle through the sacred. This points to more hope through self-determination as more resistance stories are being documented around the globe. Watching the women in the prison, I saw how some disconnected from their emotions as a survival skill, and those that did not risked a lot by not denying who they are. Touch brought voice to the silence and displayed a reciprocal relationship with healing, finding voice in the unsaid, and ironically, humbling me to listen more. Now, as I move through the world with Taana, Natalie, and Mable living in me, I have found that the skin used to organize us can reorganize us, pushing me to ask more questions through the collective imagination of the unsaid. 


\section{References}

Alexander, M. J. (2005). Pedagogies of Crossing: Meditations on Feminism, Sexual Politics, Memory, and the Sacred. Duke University Press.

Allen, P. G. (1996). "The Sacred Hoop." The Ecocriticism Reader: Landmarks in Literary Ecology. University of Georgia Press, 241-263.

Amnesty International, AI. (2014). "Entombed: Isolation in the U.S. Federal Prison System." Retrieved from http://www.amnestyusa.org/research/reports/entombed-isolation-in-the-us-federal-prisonsystem?page $=2$

Brumberg, J. J. (2010). The Body Project: An Intimate History of American Girls. Vintage Books.

Center for Constitutional Rights, CCl. (2012). "The use of solitary confinement in the U.S prison system." Retrieved from https://ccrjustice.org/home/get-involved/tools-resources/fact-sheets-andfaqs/torture-use-solitary-confinement-us-prisons

Chang, G. (2000). Disposable Domestics: Immigrant Women Workers in the Global Economy. South End Press.

Classen, C. (2012). The Deepest Sense: A Cultural History of Touch. University of Illinois Press.

Davis, A. Y. (2011). Are prisons obsolete? Seven Stories Press.

De Regt, M. (2010). "Ways to Come, Ways to Leave Gender, Mobility, and II/legality among Ethiopian Domestic Workers in Yemen." Gender \& Society, 24(2): 237-260.

Feminist Mormon Housewives (FMH), (2012). "Helen Mar Kimball: Remembering the Forgotten Women of Joseph Smith." Retrieved from: http://www.feministmormonhousewives.org/2012/02/helen-markimball-remembering-the-forgotten-women-of-joseph-smith/

---. (2014). "Emma Speaks." Retrieved from http://www.feministmormonhousewives.org/2014/11/emmaspeaks/

Farmer, P., \& Sen, A. (2003). Pathologies of Power: Health, Human Rights, and the New War on the Poor. Berkeley: University of California Press.

Field, T. (2014). Touch. MIT press.

Fogel, A. (2009). The psychophysiology of Self-Awareness: Rediscovering the Lost Art of Body Sense. WW Norton.

Gemma. (2016). "The Road to Dissent." Kohl: a Journal for Body and Gender Research, 2(2): 135-139.

Gemma, Rose, Mala, Meriam, \& Julia. (2016). "Resisting Borders: a Conversation on the Daily Struggles of Migrant Domestic Workers in Lebanon." Kohl: a Journal for Body and Gender Research, 2(2): 140153.

Harvey, D. (2005). A Brief History of Neoliberalism. Oxford University Press.

Heiss, J. (2015). "Solitary confinement isn't punishment. It's torture." The Guardian. Retrieved from https://www. theguardian.com/commentisfree/2015/jul/02/solitary-confinement-isnt-punishment-itstorture

Heylings, D. A. (1991). "The no touching epidemic-an English disease." British Medical Journal, 25(4): 653660.

Kaedbey, D. (2015). "Shadow Feminism in Lebanon, Part Two." Retrieved from http://www.sawtalniswa.org/article/481 
Kohl 3.1

Khawaja, B. (2016). "Lebanon Deports Domestic Worker Rights Organizer." Human Rights Watch. Retrieved from https://www.hrw.org/news/2016/12/13/lebanon-deports-domestic-worker-rights-organizer

Leo, K. (Producer), (2016). "Hui Mauli Ola: Empowering a People Through Healing," Episode 1 and 7. Kapono Souza \& Pōmaika'i Freed. Podcast retrieved from http://www.huimauliola.org/projects/leo-kupapodcast

Lorde, A. (2012). Sister Outsider: Essays and Speeches. Crossing Press.

Mala. (2016). "Migrating to the Lebanese Civil War." Kohl: a Journal for Body and Gender Research, 2(2): 132-134.

Moghnieh, L. (2014). "Diagnosing Hysteria in Lebanon: Psychologizing Women and Gender." Sawt Al Niswa. Retrieved from http://sawtalniswa.org/article/464\#_ftn2

Metzl, J. (2003). Prozac on the Couch: Prescribing Gender in the Era of Wonder Drugs. Duke University Press.

Nichols, J. D. (2002). Prostitution, Polygamy, and Power: Salt Lake City, 1847-1918. University of Illinois Press.

Parreñas, R. S. (2008). The Force of Domesticity: Filipina Migrants and Globalization. NYU Press.

Pande, A. (2012). "From 'Balcony Talk' and 'Practical Prayers' to Illegal Collectives Migrant Domestic Workers and Meso-Level Resistances in Lebanon." Gender \& Society, 26(3): 382-405.

Rose. (2016). "Beirut's Welcome." Kohl: a Journal for Body and Gender Research, 2(2): 125-131.

Ussher, J. M. (2010). "Are We Medicalizing Women's Misery? A Critical Review of Women's Higher Rates of Reported Depression." Feminism \& Psychology, 20(1): 9-35.

Smith, A. (2015). "Heteropatriarchy and the Three Pillars of White Supremacy: Rethinking Women of Color Organizing." Transformations: Feminist Pathways to Global Change. Routledge, 264.

Sudbury, J. (2005). "Celling Black Bodies: Black Women in the Global Prison Industrial Complex." Feminist Review, 80(1): 162-179.

Sudbury, J. (2014). Global Lockdown: Race, Gender, and the Prison-Industrial Complex. Routledge.

Walia, H., \& Smith, A. (2013). Undoing border imperialism (Vol. 6). AK Press.

World Health Organization (WHO), (2016). "Social determinants of health." Retrieved from http://www.who.int/social_determinants/en/

Van Dernoot Lipsky, L., \& Burk, C. (2010). Trauma Stewardship: An Everyday Guide to Caring for Self While Caring for Others. Berrett-Koehler Publishers. 